Сурков О. О., к.військ.н.

Центр воєнно-стратегічних досліджень Національного університету оборони України імені Івана Черняховського, Київ

\title{
Методичний підхід до формалізації стратегічного планування розвитку спроможностей Збройних Сил та інших складових сил оборони
}

Резюме. У статті запропоновано методичний підхід до формалізації стратегічного планування розвитку спроможностей Збройних Сил та інших складових сил оборони із використанням системного i структурного аналізу, декомпозиції та інших методів теоретичних досліджень для виявлення ефективних шляхів та механізмів розв'язання наявних проблем.

Ключові слова: методичний підхід; формалізація стратегічного планування; розвиток спроможностей; сили оборони; стратегічне планування.

Постановка проблеми. Пошук дієвих шляхів впровадження та здійснення стратегічного планування розвитку спроможностей Збройних Сил України та інших складових сил оборони на довгострокову перспективу для гарантованого виконання ними завдань 3 оборони держави потребує вирішення ряду завдань, серед яких важливе місце посідають вибір i впровадження методичного підходу до формалізації стратегічного планування розвитку спроможностей Збройних Сил та інших складових сил оборони.

Водночас через відсутність прийнятої та закріпленої методології стратегічного планування у сфері оборони, сталої ієрархічної системи документів, послідовності, структури i порядку їх розроблення виникають проблеми та невизначеності під час планування спільного розвитку сил оборони, насамперед на довгострокову перспективу та ефективного державного управління.

Аналіз останніх досліджень i публікацій [1-10], у яких приділено увагу розробленню наукових основ, теорії i методології будівництва Збройних Сил, систематизації $\mathrm{i}$ дослідженню закономірностей їх розвитку, свідчить, що розроблення та впровадження методичного підходу до формалізації стратегічного планування сприятиме систематизації інформації та знань про суб'єкти й об'єкти планування, формуванню логіки, послідовності дій, раціональної обробки інформації та використання їх на практиці для досягнення головної мети стратегічного планування.
Крім того, відсутність в Україні сталої ієрархічно побудованої системи документування, формалізації стратегічного планування розвитку спроможностей Збройних Сил та інших складових сил оборони, послідовності їх розроблення тощо призводить до постійного виникнення помилок під час прийняття стратегічних рішень, а також дублювання прийнятих документів.

Ці недоліки визначені в монографії В. П. Горбуліна та А. Б. Качинського [2] ще у 2010 році. Дослідники запропонували методичний підхід, сутність якого полягає в системному мисленні, що грунтується на використанні ментальних моделей. Однак використання до розроблення системи стратегічних документів (доктрини, концепції, стратегіi) тріади "національні цінності національні інтереси - національні цілі” для утворення вертикальної ієрархії $€$ не зовсім доцільним, оскільки зазначені документи $\epsilon$ підзаконними нормативно-правовими актами, які мають спиратися на Конституцію України та відповідні закони.

Отже, актуальність статті полягає в необхідності наукового осмислення існуючих методичних підходів до формалізації стратегічного планування розвитку спроможностей Збройних Сил України та інших складових сил оборони в контексті сучасної воєнної політики, вибору пріоритетних напрямів та шляхів удосконалення системи стратегічного планування в секторі безпеки і оборони України.

Метою статті $\epsilon$ висвітлення підходу до формалізації стратегічного планування розвитку спроможностей Збройних Сил 
України та інших складових сил оборони, який дасть змогу вдосконалити існуючу систему планування в секторі безпеки i оборони України.

Викладення основного матеріалу. Стратегічне планування розвитку спроможностей Збройних Сил України та інших складових сил оборони (СПРС 3С України та ICCO) у цій статті розуміється як управлінський процес, який організовується та здійснюється 3 метою розроблення стратегічних документів, які визначають стратегію розвитку необхідних спроможностей сил оборони, їх підготовку та застосування для оборони держави, захисту їі суверенітету, територіальної цілісності і недоторканності.

Будь-який управлінський процес (система) може бути процедурою процесу вищого рівня (підсистемою). Отже, СПРС ЗС України та ICCO розглядається як підсистема стратегічного планування в секторі безпеки i оборони України (державного стратегічного планування), яка містить певні компоненти, підсистеми й елементи, пов'язані між собою інформаційними зв'язками, що становлять єдину цілісність. У свою чергу управлінський процес передбачає формування та розроблення відповідних документів за результатами певних взаємопов'язаних процедур, етапів, кроків, заходів для досягнення визначеної мети і часткових цілей.

Формування i розроблення пакету стратегічних документів для розвитку спроможностей ЗС України та ICCO не $\epsilon$ винятком та потребує використання відповідного методичного підходу, сучасної методології та належного обсягу наукових знань.

Термін “формалізація” у цій статті означає метод відображення процесу у вигляді формальної системи для зручності вивчення предмета із використанням системного та структурного аналізу, декомпозиції та інших методів теоретичних досліджень [9].

Результати останніх досліджень i публікацій показують, що більшість із них стосується сфери бізнесу (економіки) і лише незначна частина - сфери оборони i військового будівництва у мирний час та особливий період, а саме застосування методології стратегічного планування розвитку спроможностей Збройних Сил та інших складових сил оборони на довгострокову перспективу. Наявні підходи до формалізації стратегічного планування не враховують специфіки цього процесу, обмежені сферою застосування або розробленням конкретних нормативних документів, не мають чіткого системного узгодження 3 державною системою прогнозування та стратегічного планування, плануванням соціально-економічного розвитку України та бюджетним плануванням i, як правило, не забезпечують належного оцінювання циклічного розроблення документів стосовно розвитку спроможностей сил оборони.

Про недосконалість в Україні відповідної нормативно-правової бази щодо визначення засад стратегічного планування у сфері національної безпеки та оборони держави свідчить, зокрема, відсутність політичної волі Парламенту України до прийняття Закону України "Про державне стратегічне планування", проект якого зареєстровано 03.11.2011 за № 9407 із подальшою редакцією від 04.12.2017. Тривалий час перебуває на розгляді у Верховній Раді України внесений Президентом України проект Закону України "Про національну безпеку України”, складовою якого $\epsilon$ розділ V "Планування у сфері національної безпеки і оборони".

Крім того, не ухвалено довгострокові стратегії національної безпеки, зокрема Стратегію воєнної безпеки України, передбачену Законом України "Про організацію оборонного планування" [11]. Порядок організації та фінансування стратегічного планування у сфері оборони i військового будівництва [12] розроблено без посилання на норми відповідних законів України, що вплинуло на рівень обороноздатності держави та готовність усіх складових сектору безпеки i оборони, передусім сил оборони, до спільних (консолідованих) дій та відбиття збройної агресії проти України.

У МО України та ЗС України триває впровадження процесу оборонного планування у сфері оборони на засадах планування розвитку спроможностей сил оборони в рамках оборонної реформи [13-18]. Як “спроможності Збройних Сил (сил оборони)" прийнято розуміти здатність структурної одиниці (елемента) Збройних Сил (сил оборони) або сукупності сил і засобів виконувати визначені завдання (забезпечувати досягнення намічених військових цілей) за певних умов обстановки, ресурсного забезпечення та відповідно до встановлених стандартів.

Базові компоненти (складові) спроможностей, вимоги до них, функціональні групи (інтегровані категорії) спроможностей, 
термінологію

тощо [18]

прийнято застосовувати у ході оборонного планування, яке згідно із Законом України [11] $є$ складовою системи стратегічного планування та управління державними ресурсами у сфері оборони.

За результатами проведених досліджень щодо систематизації, уточнення та розвитку понятійного апарату [4-7] СПРС ЗС України та ICCO, перегляду стратегічних цілей, пріоритетів, напрямів і завдань їх розвитку, цей процес формалізовано через загальну структуру думок та сформульовані на цій основі правила міркування.

1. Будь-який складний процес $\epsilon$ циклічним, його можна розглядати як складну систему, що містить взаємопов'язані процедури, притаманні плануванню у різних сферах національної безпеки. Наприклад, стратегічне планування містить п’ять основних процедур: аналіз безпекового середовища; прогнозування ситуацій та сценаріїв; прогнозування видатків; розроблення стратегіï; моніторинг.

2. Процедури обраного процесу містять взаємопов' язані етапи. Наприклад, процедура "аналіз безпекового середовища" передбачає такі етапи: аналіз воєнно-політичної обстановки, аналіз воєнно-стратегічної обстановки тощо.
3. Етапи містять кроки, які обирають залежно від етапу, поділяючи його на елементи.

4. Кроки містять основні заходи, які необхідно провести відповідним організаційним структурам (посадовим особам) у ході відповідного етапу планування.

5. Основні заходи містять результативні показники та вихідні дані (проведені розрахунки, розроблені документи тощо) для наступних процедур.

6. Стратегічне планування у сфері оборони є складовою системи планування у сфері національної безпеки.

7. Засади й основні вимоги до стратегічного планування мають бути закріплені нормативно-правовими актами i прийнятими на їх виконання нормативними документами.

За юридичною силою нормативноправові акти (НПА) поділяють на дві великі групи: закони і підзаконні акти [8]. Закон має вищу юридичну силу та регулює найважливіші суспільні відносини, отже, підзаконні акти мають відповідати закону і не суперечити його нормам.

За результатами аналізу (за юридичною силою, суб' єктами законотворчості, структурою, сферою діï) структуру чинної системи НПА наведено на рис. 1.

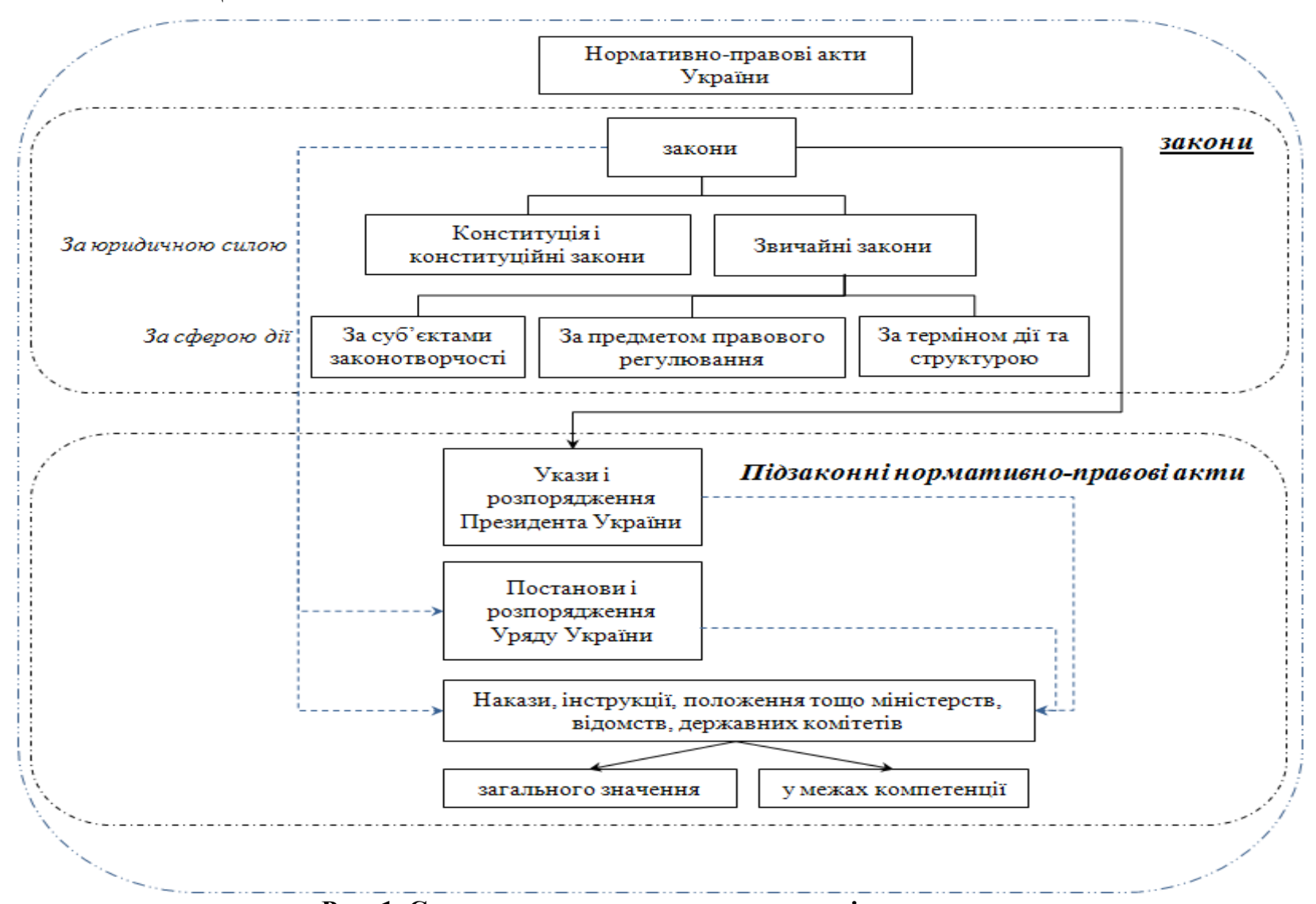

Рис. 1. Система нормативно-правових актів держави 
Для аналізу чинних НПА щодо СПРС 3С України та ICCO, їх впорядкування та вдосконалення, приведення до певної внутрішньої узгодженості через створення зв'язків наступним етапом обрано класифікацію системи НПА (див. рис. 1) за рівнями ієрархії.

За сформованою системою та проведеною класифікацією проаналізовано чинні НПА щодо СПРС ЗС України та ICCO для їх впорядкування та вдосконалення, приведення до певної внутрішньої узгодженості через виявлення інформаційних зв' язків.

Крім того, аналіз чинних НПА за назвою, преамбулою, посиланням на акт вищого рівня, їх взаємозв'язком 3 іншими актами, стосунком до законно створених військових формувань, назвами статей актів та змістом свідчить про недосконалість i розбалансованість законодавства щодо державного стратегічного планування. На це вказує відсутність станом на сьогодні чинних правових та організаційних засад системи стратегічного планування в секторі безпеки $\mathrm{i}$ оборони України, невизначеність загального порядку їх розроблення, затвердження i виконання документів державного стратегічного планування, у тому числі СПРС 3С України та ICCO, а також повноважень учасників цих процесів.

За результатами проведеного дослідження сформовано сукупність основних вимог до системи документів СПРС ЗС України та ICCO (рис. 2).

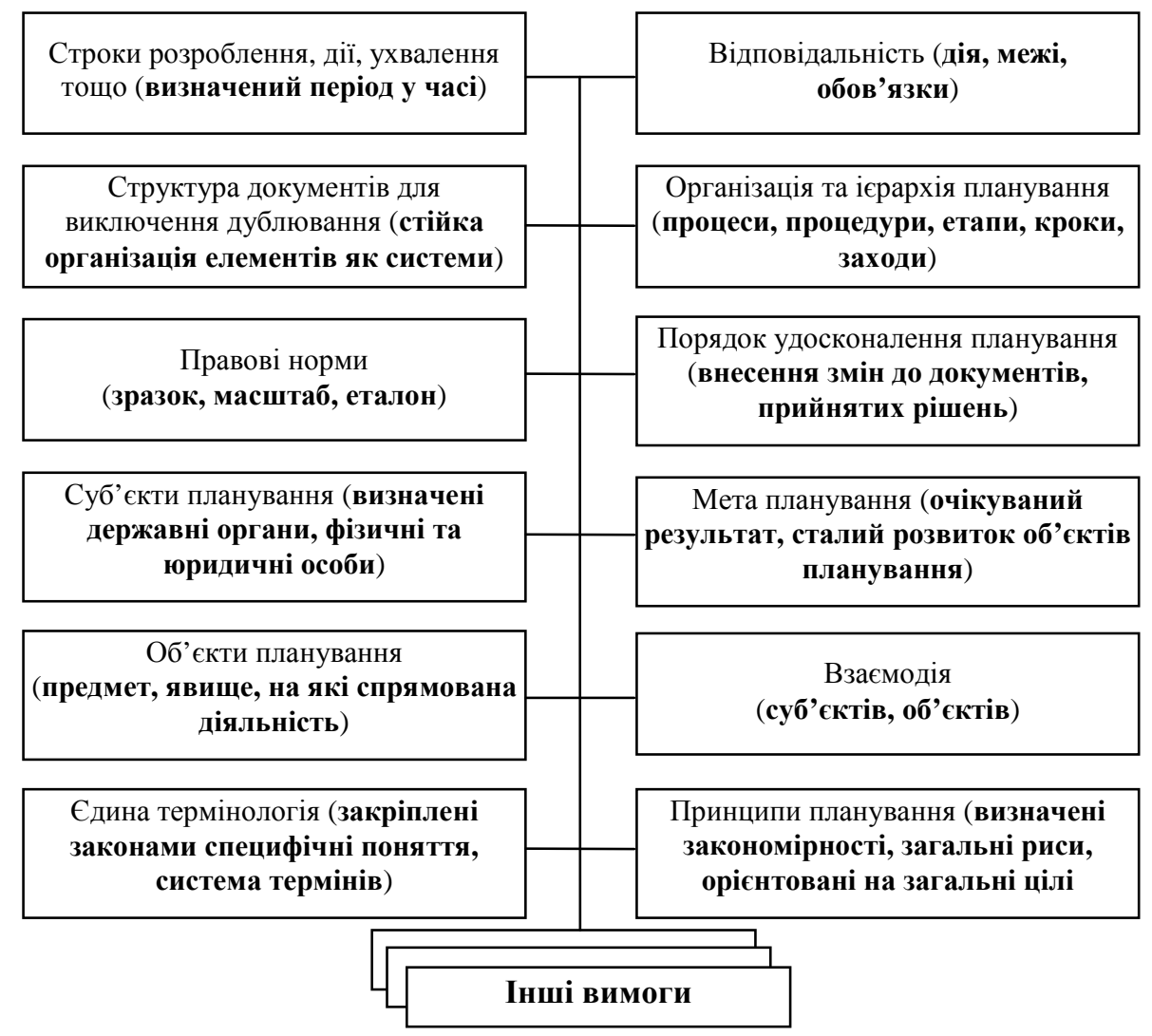

Рис. 2. Сукупність основних вимог до системи документів стратегічного планування розвитку спроможностей Збройних Сил України та інших складових сил оборони

Наведені вимоги є лише припущеннями, що відображають проблемні питання розроблення та впровадження ефективних методів і моделей стратегічного планування.

Наприклад, вимога щодо структури документів для виключення дублювання (див. рис. 2) є одним із чинників, який впливає на ієрархію системи документів СПРС 3С України та ICCO і передбачає стійку організацію його елементів як системи, що дає можливість застосовувати документ на практиці і не дублювати інші.

Через стохастичність стану СПРС ЗС України та ICCO і нелінійність більшості процесів та процедур у цій сфері необхідно вдосконалити процес на державному рівні.

Стратегічне планування має сприяти прийняттю ефективних управлінських рішень 
для проведення результативних заходів, пов'язаних із вибором стратегічних цілей, розробленням відповідних стратегій i стратегічних документів, що визначатимуть напрями всебічного розвитку його складових на певний період та базуватимуться на результатах комплексного оборонного огляду усіх складових сил оборони 3 урахуванням соціально-економічних можливостей (стану) держави.

Проведені дослідження теоретикометодологічних проблем формування НПА 3 питань забезпечення національної безпеки підтверджують існування невизначеностей в ієрархії НПА у сфері забезпечення національної безпеки та пріоритетності їх розроблення, затвердження й уточнення. Для усунення невизначеностей у [2] запропоновано підхід, суть якого полягає в застосуванні системного мислення на основі ментальних моделей.

Обгрунтована тріада системи стратегічних документів (доктрина, концепція, стратегія) утворює вертикальну i горизонтальну ієрархії для розроблення документів на національному рівні [2]. Разом iз цим такий підхід не враховує закони (право), які по суті мають найвищу юридичну силу, утверджують встановлені законодавчим органом загальнообов'язкові норми, спрямовані на регулювання суспільних потреб, у тому числі розраховані на неоднарозове застосування.

Наприклад, у Законі України "Про організацію оборонного планування” [11] визначені завдання, принципи, зміст і порядок оборонного планування у сфері оборони та порядок координації дій органів державної влади (Ради національної безпеки і оборони України, Рахункової палати, Кабінету Міністрів України, центральних органів виконавчої влади).

Останнім проектом Закону України "Про державне стратегічне планування” [19] передбачено визначення правових та організаційних засад формування цілісної системи державного стратегічного планування розвитку країни, встановлення загального порядку розроблення, затвердження i виконання документів державного стратегічного планування, а також повноважень учасників цих процесів.

Отже, у складі тріади системи стратегічних документів (доктрина, концепція, стратегія) слід розглядати закони (право), відповідно побудувати таку нормативноправову вертикаль актів у сфері національної безпеки i оборони України щодо СПРС 3С України та ICCO: закон - стратегія концепція.

Проте і ця тріада не є повною, оскільки у ній слід розглядати ще й доктрини, засади, Стратегічний оборонний бюлетень, стратегічні плани, які по суті належать до системи стратегічних документів й утворюють рівні нормативно-правового регулювання суспільних відносин у сфері національної безпеки i оборони України.

Інші нормативні документи мають деталізувати стратегію через сплановані конкретні заходи. Однак доктрина не визнана офіційним джерелом права, концепція закріплює головні політичні принципи держави у зазначеній сфері (наприклад, Концепція розвитку сектору безпеки і оборони України), стратегію як i концепцію та доктрину, має схвалювати Президент України своїм указом.

Для систематизації, уточнення та розвитку понятійно-категорійного апарату щодо стратегічного планування необхідно додатково проаналізувати, класифікувати й уточнити сутність існуючих понять (термінів).

Найскладнішим i одночасно найменш дослідженим питанням є вибір і обгрунтування показників та критеріїв оцінювання, що сприятимуть прийняттю обгрунтованих рішень під час усіх процедур стратегічного планування i управління, оскільки не всі аспекти можна кількісно оцінити без залучення експертів та застосування відповідних коефіцієнтів важливості.

Таким чином, за результатами проведених досліджень щодо сутності та призначення системи стратегічних документів iз планування розвитку спроможностей ЗС України й інших складових сил оборони, запропоновано рівні ієрархії документів (див. рис. 1), які доцільно взяти за основу у практиці формалізації СПРС ЗС України та ICCO для прийняття обгрунтованих рішень.

\section{Висновки.}

1. Запропонований методичний підхід до формалізації стратегічного планування розвитку спроможностей Збройних Сил та інших складових сил оборони із використанням системного i структурного аналізу, декомпозиції та інших методів теоретичних досліджень комплексно враховує особливості цього процесу.

2. Організацію і порядок стратегічного планування розвитку спроможностей Збройних Сил та інших складових сил оборони (державного стратегічного планування) доцільно визначити відповідним законом та 
іншими нормативно-правовими актами, розробленими з урахуванням запропонованого методичного підходу та на основі сучасної теорії i практики, а також зарубіжного досвіду.

3. Сформована сукупність основних вимог до системи документів стратегічного планування розвитку спроможностей Збройних Сил та інших складових сил оборони дала змогу розглянути об'єкт наукового дослідження як консолідований процес, виявити ефективні шляхи та механізми розв'язання наявних проблем.

Перспективою подальших досліджень 3 урахуванням отриманих результатів є вибір методів для обгрунтування вимог до спроможностей, вибір пріоритетних напрямів стратегічного планування розвитку спроможностей і подальша деталізація формалізації процесів та процедур.

\section{СПИСОК ВИКОРИСТАНОЇ ЛІТЕРАТУРИ}

1. Ситник Г. П. Концептуальні засади забезпечення національної безпеки України: навч. посіб.: у 3 ч. Ч.3: Державна політика та основи стратегічного планування забезпечення національної безпеки / Г. П. Ситник. - К.: НАДУ, 2010. - 208 с.

2. Горбулін В. П. Стратегічне планування: вирішення проблем національної безпеки: монографія / В. П. Горбулін, А. Б. Качинський. К.: НІСД, 2010. - 288 с.

3. Богданович В. Ю. Теоретико-методологічні засади забезпечення національної безпеки держави у ії визначальних сферах: монографія / В. Ю. Богданович. - К.: Кий, 2007. - 370 с.

4. Сурков О. О. Досвід стратегічного планування / О. О. Сурков,

Ф. В. Саганюк,

В. Я. Мірошниченко, В. А. Коваленко // Оборонний вісник НАСВ. - 2016. - № 8. - С. 2427.

5. Сектор безпеки і оборони України: стратегічне планування / Ф. В. Саганюк, М. М. Лобко, О. В. Устименко, А. К. Павліковський; за ред. Р. I. Тимошенка. - К.: Майстер книг, 2016. $248 \mathrm{c.}$

6. Сурков О. О. Підхід до визначення сутності понять “спроможність", “можливість", “здатність" сил оборони для вдосконалення основ стратегічного планування // Зб. наук. праць ЦВСД НУОУ. - 2017. - № 1 (59). - С. 35-40.

7. Сектор безпеки i оборони України: теорія, стратегія, практика: монографія / [Ф. В. Саганюк,
В. С. Фролов, О. В. Устименко та ін.]. - К.: Академпрес, 2017. - 180 с.

8. Зайчук О. В. Теорія держави і права. Академічний курс: підручник / О. В. Зайчук , Н. М. Оніщенко. К.: Юрінком Інтер, 2006. - 288 с.

9. Орловский П. Н. Системный анализ: учеб. пособ. [для студ. экон. спец.] / П. Н. Орловский. - К.: Институт содержания и методов обучения, 1996. $360 \mathrm{c.}$

10. Сучасний тлумачний словник української мови: 100000 слів/ за заг. ред. д-ра філол. наук, проф. В. В. Дубічинського. - Харків: ВД “ШКОЛА", 2011. - 1008 c.

11. Закон України "Про організацію оборонного планування” від 18.11.2004 № 2198-IV.

12. Постанова Кабінету Міністрів України “Про затвердження Порядку організації та фінансування стратегічного планування у сфері оборони i військового будівництва” від 05.04.2006 № 447.

13. Указ Президента України "Про рішення Ради національної безпеки i оборони України від 06.05.2015 "Про Стратегію національної безпеки України” від 26.05.2015 № 287/2015.

14. Указ Президента України "Про Рішення Ради національної безпеки i оборони України від 02.09.2015 "Про нову редакцію Воєнної доктрини України” від 24.09.2015 № 555/2015.

15. Указ Президента України "Про Рішення Ради національної безпеки і оборони України від 04.03.2016 "Про Концепцію розвитку сектору безпеки i оборони України” від 14.03.2016 № 92/2016.

16. Указ Президента України "Про Рішення Ради національної безпеки i оборони України від 20.05.2016 “Про Стратегічний оборонний бюлетень України” від 06.06.2016 № 240/2016.

17. План дій щодо впровадження оборонної реформи у 2016-2020 роках (Дорожня карта оборонної реформи): затв. МО України 15.08.2016 [Електронний ресурс]. - Режим доступу: http://www.mil.gov.ua/diyalnist/reformi-taplanuvannya-u-sferi-oboroni/22082016-04.html.

18. Рекомендації з оборонного планування на основі спроможностей в Міністерстві оборони України та Збройних Силах України: затв. Міністром оборони України 12.06.2017 [Електронний ресурс]. - Режим доступу: http://www.mil.gov.ua/diyalnist/reformi-taplanuvannya-u-sferi-oboroni/.

19. Проект Закону України "Про державне стратегічне планування” від 03.11.2011 та 04.12.2017 [Електронний ресурс]. - Режим доступу: http://w1.c1.rada.gov.ua/pls/zweb2/ webproc4_1?pf3511=41685). 
Сурков О. А., к.воен.н.

Центр военно-стратегических исследований Национального университета оборони Украины имени Ивана Черняховского, Киев

Методический подход к формализации стратегического планирования развития возможностей Вооруженных Сил и других составляющих сил обороны

Резюме. В статье предложены некоторые пути внедрения разработанного методического подхода к формализации стратегического планирования развития возможностей Вооруженных Сил и других составляющих сил обороны для принятия обоснованных решений.

Ключевые слова: методический поход; формализация стратегического планирования; развитие возможностей; силы обороны;стратегическое планирование.

\section{O. Surkov, PhD (Military)}

Center for Military and Strategic Studies of the National Defence University of Ukraine named after Ivan Cherniakhovskyi, Kyiv

Methodical approach to strategic planning formalization for capability development of the Armed Forces and other components of the Defense Forces

Resume. The article suggests some ways of implementing the developed methodological approach to formalizing the strategic planning for the development of the capabilities of the Armed Forces and other components of the defense forces to make informed decisions.

Keywords: methodical approach; formalization of strategic planning; capacity development; defense forces; strategic planning. 